\title{
EFFECTS OF INITIAL MOISTURE CONTENT ON THE PRODUCTION AND QUALITY PROPERTIES OF SOLID BIOFUEL
}

\author{
Miloš Matúš**, Peter Križan, Juraj Beniak, Lubomír Šooš \\ Slovak University of Technology in Bratislava, Faculty of Mechanical Engineering, Namestie slobody 17, 81231 \\ Bratislava, Slovak Republic \\ * corresponding author: milos.matus@stuba.sk
}

\begin{abstract}
The moisture content of densified biomass is a limit parameter influencing the quality of the solid biofuel. It influences its calorific value, density, mechanical strength and dimensional stability as well as the production process of this biofuel. The paper deals with the experimental research of the effect of moisture content of densified material on the final quality of biofuel in the form of logs. Experiments based on the single-axis densification of spruce sawdust were realized by hydraulic piston press, where the densified logs were produced under room temperature. The effect of moisture content on the quality properties of the logs, including density, change of moisture, expansion and physical changes, were studied. The results show the necessary moisture ranges for producing good-quality logs. The experiments were evaluated and the moisture content of the tested material was optimized to achieve the optimum value for the best quality of the solid biofuel.
\end{abstract}

KEYWORDS: biomass; densification; solid biofuel; moisture; briquettes; pellets.

\section{INTRODUCTION}

The production of high quality solid biofuel brings many advantages compared to nondensified fuels. The uneven, fluffy, and dusty characteristics of biomass often make the material difficult to store, transport, and utilize. Densified biomass fuel can ease these problems. The higher bulk and energy densities result, respectively, in lower costs of transportation, handling and storage, and higher energy conversion efficiency, while the reduced moisture content increases the long term storage capability [2, 10].

The strength and durability of the densified products depend on the physical forces that bond the particles together. The binding forces that act between the individual particles in densified products have been categorized into five major groups 1, 4, 7, 13. They are (i) solid bridges, (ii) attraction forces between solid particles, (iii) mechanical interlocking bonds, (iv) adhesion and cohesion forces, and (v) interfacial forces and capillary pressure.

The final moisture content of the pellets or briquettes from biomass is greatly dependent on process conditions such as initial moisture content, temperature, and pressure. Water acts both as a binding agent and a lubricant. The moisture present in the biomass facilitates starch gelatinization, protein denaturation, and fiber solubilization processes during extrusion, pelleting, or briquetting [6, 8, 12, 14]. Water helps develop Van der Waals' forces by increasing the area of contact between particles, according to [15]. According to [16], initial moisture content higher than $15 \%$ and pressure higher than $15 \mathrm{MPa}$ have a negative effect on the final briquette quality, where cracks have been observed. Pellets with moisture content lower than $5 \%$ can result in revenue loss for the pellet manufacturer, as they tend to break up, creating more fines during storage and transportation. Pellets with high moisture content can be subject to spoilage due to bacterial and fungal decomposition, resulting in significant dry matter losses during storage and transportation [14, 17]. Steam-treated biomass is superior, as the additional heat modifies its physiochemical properties (gelatinization of starch, denaturation of protein) to such an extent that binding between the particles is significantly enhanced, resulting in improved densification quality [18]. In study [19] it was found that increasing the moisture content of spruce wood sawdust from 7 to $15 \%$ significantly increased the strength of the pellets. The authors of study 2 researched the compaction of tree bark, sawmill waste, wood shavings, alfalfa hay, fresh alfalfa, and grass in a punch and die assembly and found that an optimum moisture content of approximately $8 \%$ was recommended to produce high-density briquettes. They also recommended that a moisture content of $5-12 \%$ is necessary to produce good quality (in terms of good density and long-term storage properties) logs from hardwood, softwood, and bark in the forms of sawdust, mulches, and chips. They also remarked that pellets or briquettes tend to become fragile in just a few days if the moisture content is lower than $4 \%$ due to absorption of moisture from the environment [2]. Densification of alfalfa having a lower moisture content and fewer long fibers (more fines) had resulted in more stable wafers, due to limited expansion. Alfalfa pellets made at $19 \%$ moisture content had the highest durability [20]. The optimum moisture content for 


\begin{tabular}{cc}
\hline $\begin{array}{c}\text { Particle } \\
\text { size }[\mathrm{mm}]\end{array}$ & $\begin{array}{c}\text { Proportion } \\
\text { by weight }[\%]\end{array}$ \\
\hline$\geq 4.00$ & 2.56 \\
$2.00-4.00$ & 12.69 \\
$1.00-2.00$ & 35.92 \\
$0.50-1.00$ & 26.06 \\
$<0.50$ & 22.77 \\
\hline
\end{tabular}

TABLE 1. Raw material particle size distribution of Norway spruce sawdust.

pelleting cellulosic materials is $8-12 \%$ [21. A study of briquetting sawdust, sander dust, wood shavings, and peanut hulls reported that $15 \%$ moisture content is favourable 222. The results of 23 show that initial moisture content of the raw material is the most important variable for controlling moisture uptake in the production of Norway spruce pellets. In study [9], dealing with the pelleting of Scots pine, the moisture content is the dominant factor for bulk density and pelletizer motor current, which is explained by the alteration of the friction through the die due to the lubricating property of water. The study also reported that an optimum pellet quality was obtained at storage times longer than 120 days and within a range of moisture content of 11-13\%. Many researchers have found that the optimum moisture content for the densification of biomass is different for each individual raw material and operating condition.

The commercially most used pressure agglomeration machines for the densification of biomass materials are ram (piston-type) extrusion presses, screw extruders, and pelletizers (ring-die, flat-die) [11]. In piston presses and screw extruders, the raw material is conveyed and compressed by a piston or a screw through a die to form briquettes of cylindrical or other shapes. In pelletizers, the material is pressed through openended cylindrical holes (dies) made in the flat plate or in the periphery of the ring. One to three small rotating rolls push the feed material into the die holes. The skin friction between the feed particles and the wall of the die resist the free flow of feed and thus the particles are compressed against each other inside the die to form pellets [11, 12.

Based on the above analysis of the effect of moisture content, the aim of this study is to determine the optimal initial moisture content for Norway spruce sawdust to achieve the best quality of briquettes in the industrial briquetting process. A high-pressure compaction process by piston and die was used to densify the biomass materials in this study. The hydraulic press used is a conventional production briquetting press. The densification process of this press can achieve high and uniform pressure so that dense and strong briquettes can be produced under normal temperature without having to use a binder or heat. Materials can be compacted rapidly at room temperature to form good-quality products.

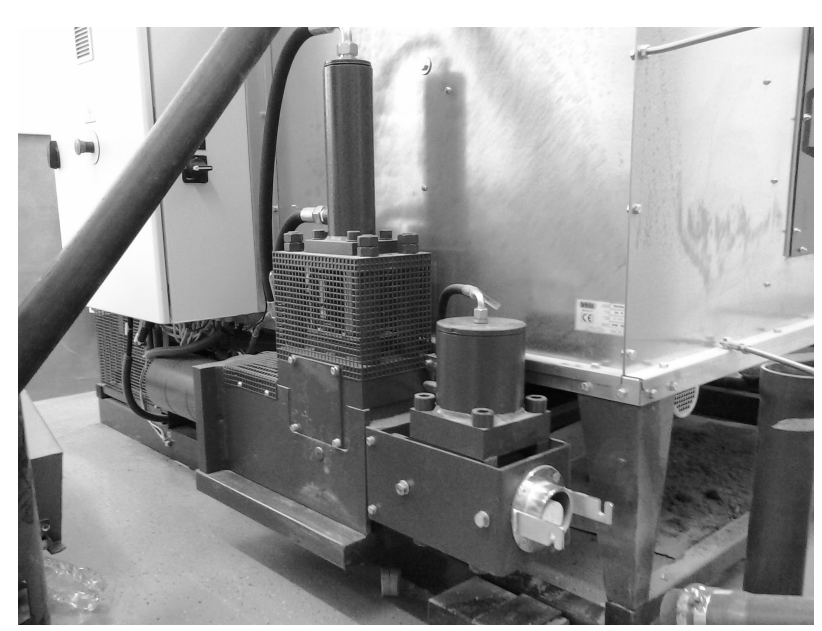

Figure 1. Production hydraulic briquetting press.

\section{MATERIAL AND METHODS}

\subsection{RAW MATERIAL}

Fresh sawdust of Norway spruce (Picea abies) originating from West Slovakia was obtained from a sawmill where it had been dried to a moisture content of $8.2 \%$ and milled in a hammer mill. The sawdust contained no bark.

Approximately 1.5 tonnes of the prepared raw material were transported to the Biomass Laboratory of the Faculty of Mechanical Engineering of the Slovak University of Technology in Bratislava, Slovakia. The material was stored in laboratory in big-bags for six months before the experiments. The particle size distribution was analysed on a representative seven samples of $100 \mathrm{~g}$ by the Retsch Vibratory Sieve Shaker AS 200 digit. The raw material particle size distribution was determined according to Table 1.

Nine samples with different initial raw material moisture contents were prepared six days before the densification. Particular material samples were weighed and the exact amount of water at a temperature of $15^{\circ} \mathrm{C}$ was added by spraying. Every sample was mixed to homogenize the moisture and stored in plastics bags. The values of initial moisture content of the samples measured immediately before the densification process were $7.4 \% ; 9.1 \% ; 10.3 \% ; 11.7 \%$; $12.6 \% ; 14.5 \% ; 16.5 \% ; 19.6 \%$ and $22.0 \%$ w.b. The range of moisture content was designed to include the whole interval in which the densification of biomass is possible and the values of moisture content are close enough to get exact results.

\subsection{Densifichtion process}

The briquettes were produced in an industrial-scale process with a BrikStar 200 (BRIKLIS, s.r.o., Czech Republic) hydraulic briquetting press equipped with a cylindrical open die with a diameter of $50 \mathrm{~mm}$ and a length of $340 \mathrm{~mm}$. The densification process of biomass is caused by a moving piston from one side of the die and the frictional resistance of briquettes into the die. Increasing friction dependent on the length 


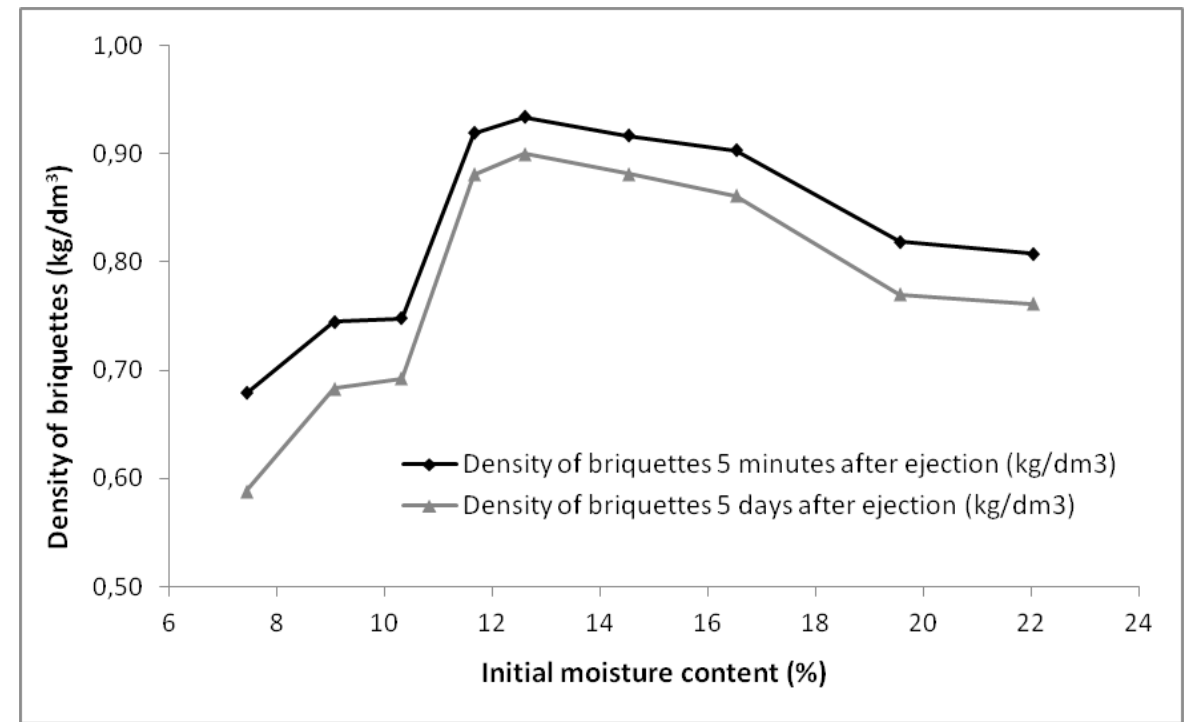

FiguRE 2. Variation of log density with initial moisture content of spruce sawdust compacted at $16.5 \mathrm{MPa}$.

of the die causes higher compacting pressure on the raw material.

After the raw material was fed by screw and precompacted by side piston, pressure was applied at a constant rate by the main piston. When the pressure reached the desired value, the main piston moved back immediately without delay.

The hydraulic press allows its users to program the length of the briquettes and to constrict the die. The length of the briquettes depends on the raw material and on feeding parameters. A constant briquette length (30\% of its maximum), constant feeding parameters and an ultimate densification pressure of 16.5 $\mathrm{MPa}$ were used in this study. Furthermore, the constriction of the die was not used during the densification process. During the processing, the temperature of the briquettes was measured and it reached up to $30^{\circ} \mathrm{C}$.

\subsection{SAMPLING}

Once the briquetting process had reached a steady state and briquettes with the same initial moisture content had a similar appearance, a sampling of 40 briquettes was conducted. Thirty of them were selected for measurement of physical characteristics and ten of them for measurement of moisture content. The sampling was repeated nine times separately for every prepared raw material with a different initial moisture content. All samples were marked and stored at $20^{\circ} \mathrm{C}$ in laboratory. In total, $9 \times 40$ briquettes were collected.

\subsection{Moisture Content}

The moisture content of the briquettes was measured in two stages: (i) 5 minutes after ejection, and (ii) 5 days after ejection. The moisture content was determined by heating the material (disintegrated briquette) at $105 \pm 2{ }^{\circ} \mathrm{C}$ until a constant weight was achieved according to the standard procedure described in EN 14774-3:2009 [3].

\subsection{WEIGHT, DIMENSIONS AND DENSITY}

The weight, length and diameter of each briquette were measured using a digital calliper and an electronic balance. Briquette density was calculated by means of the ratio between the weight of a briquette and its volume, including pore volume. The volume of the briquettes was calculated as the volume of a cylinder with dimensions (length and diameter) measured as previously described, according to EN 16127:2012 [5]. The average density was calculated for each sample of 30 briquettes with different raw material initial moisture contents.

The briquette densities were measured 5 minutes after the briquettes were ejected from the die. Other properties of the briquettes were tested 5 days after the briquettes were made and stored in air in the laboratory. The 5-minute density was chosen because most of the briquettes underwent expansion after their ejection and the most rapid expansion occurred within the first 5 minutes.

\section{Results AND Discussion}

\subsection{EFFECT OF MOISTURE CONTENT ON DENSITY}

The effect of moisture content on briquette density was studied extensively in two stages: (i) five minutes after ejection, and (ii) five days after ejection. Fig. 2 shows both densities of the briquettes ( 5 minutes after ejection and 5 days after ejections) made at 16.5 $\mathrm{MPa}$ without holding time, as a function of the initial moisture content. When the moisture content was lower than $11 \%$, the briquettes had low densities and were easy to disintegrate when subjected to small handling forces. They tended to absorb moisture from the air and expanded significantly, becoming fragile 


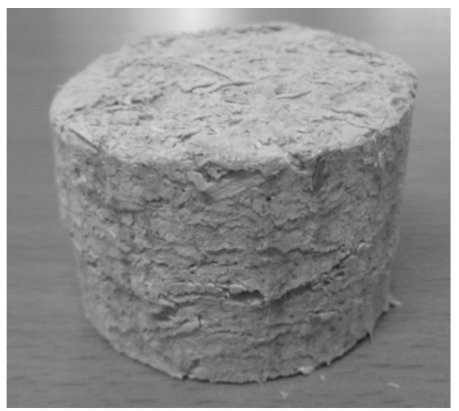

$7.4 \%$

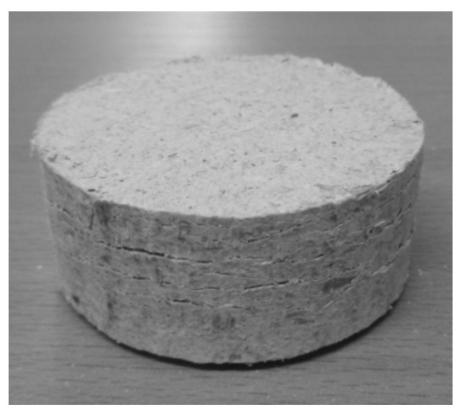

$11.7 \%$

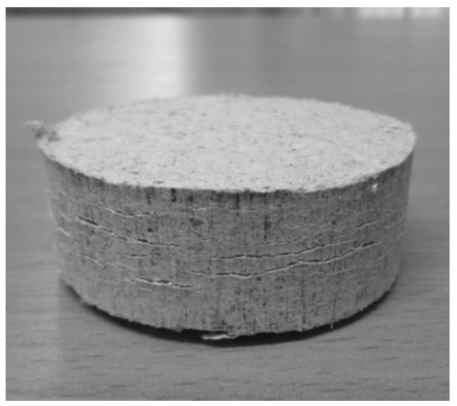

$16.5 \%$

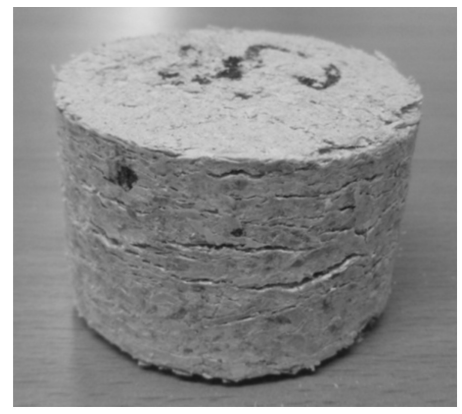

$9.1 \%$

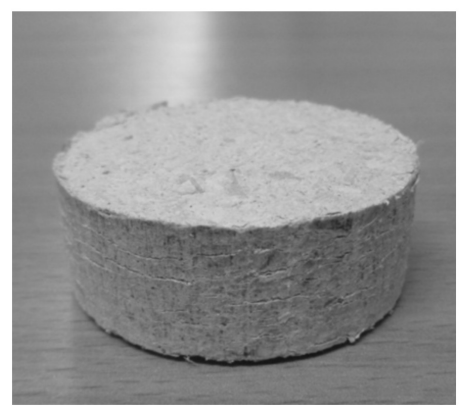

$12.6 \%$

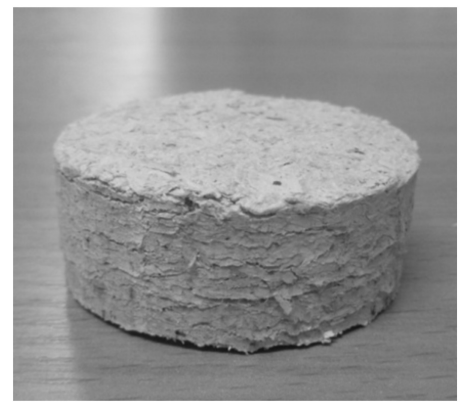

$19.6 \%$

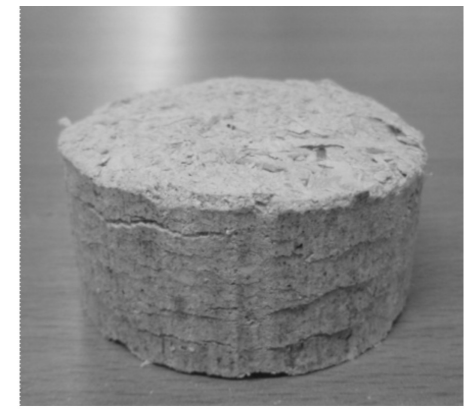

$10.3 \%$

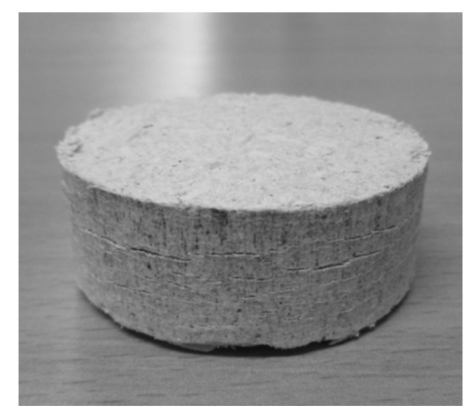

$14.5 \%$

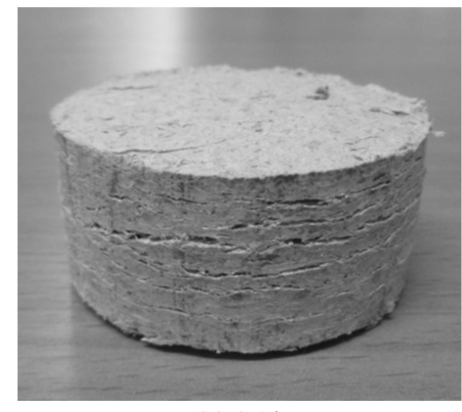

$22.0 \%$

FiguRE 3. Biomass briquettes of spruce sawdust with different initial moisture contents compacted without holding time at $16.5 \mathrm{MPa}$ and room temperature by the BrikStar 200 industrial manufacturing hydraulic briquetting press; optical comparison of the surface quality.

in a few days. On the other side, the briquettes with initial moisture content higher than $17 \%$ could not maintain their good quality for long because their volumes grew markedly immediately after ejection from the die and because of the significant cracks created on the surface. Fig. 2 also shows the rather stable change of the briquette density after 5 days through the whole tested interval of initial moisture content. The briquettes made at around $12.6 \%$ initial moisture content had the highest density and the surface was also smooth, without visible cracks.

The surface quality of briquettes with different initial moisture contents is optically compared in Fig. 3 . Cracks and porosity decreased with increasing initial moisture content up to around $11 \%$ w.b. A moisture content higher than $14.5 \%$ caused an increase in the surface porosity and cracks again. The best surface quality was achieved with the moisture range from $12.6 \%$ to $14.5 \%$.

The results of the experiments also showed that the weight of particular briquettes slightly decreased with the increasing moisture of raw material. All control parameters of briquetting press and particle size distribution were constant. This fact is caused by changes in the bulk density of sawdust when its moisture content is changed.

\section{EXPANSION AND PHYSICAL CHANGES}

The briquettes made at around $12.6 \%$ moisture content had the highest density and a good long-term performance. This phenomenon can be seen in Fig. 4. which shows the expansion of the briquettes made of spruce sawdust at different initial moisture contents after 5 days. The longitudinal expansions (elongations) in 5 days were calculated on the basis of the lengths of the briquettes measured 5 minutes after ejection from the die and then re-measured 5 days later. The elongation was reduced after 5 days when the initial moisture content increased. The experiments proved the briquette length shrinking (negative elongation) during 5 days when the initial moisture content got over around $21 \%$.

Fig. 5 shows the percentage of the change in briquette density with initial moisture content of spruce 


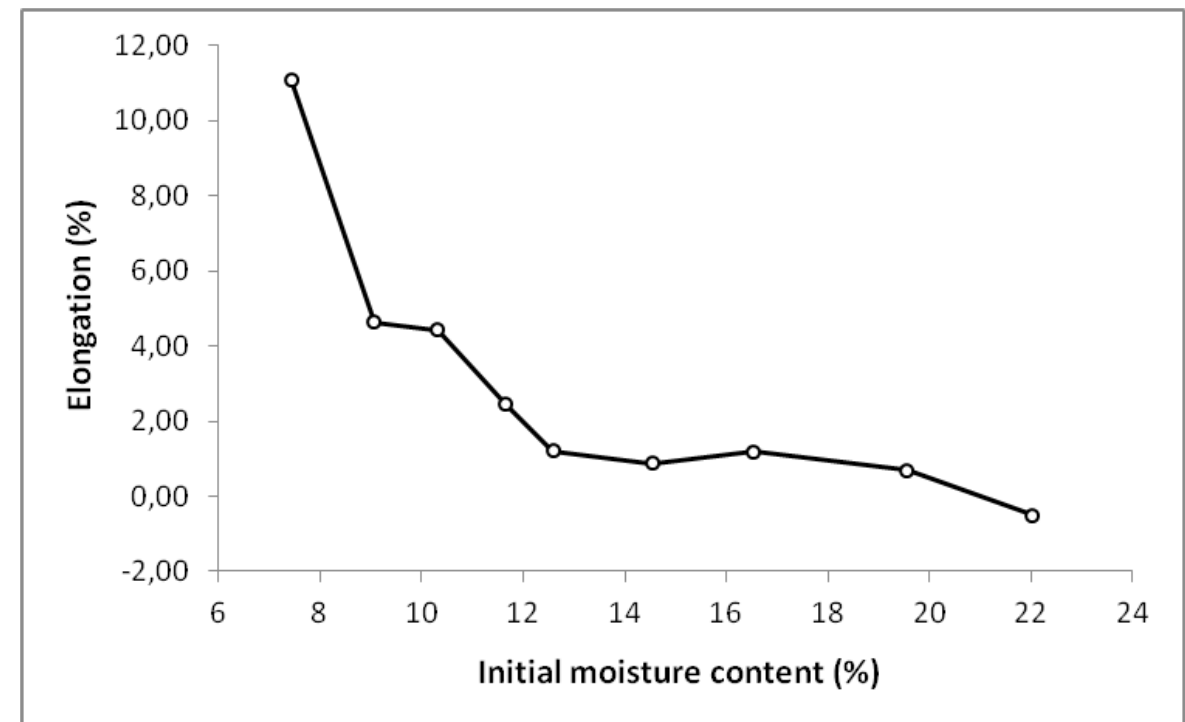

FiguRE 4. Variation of elongation of briquettes with initial moisture after 5 days.

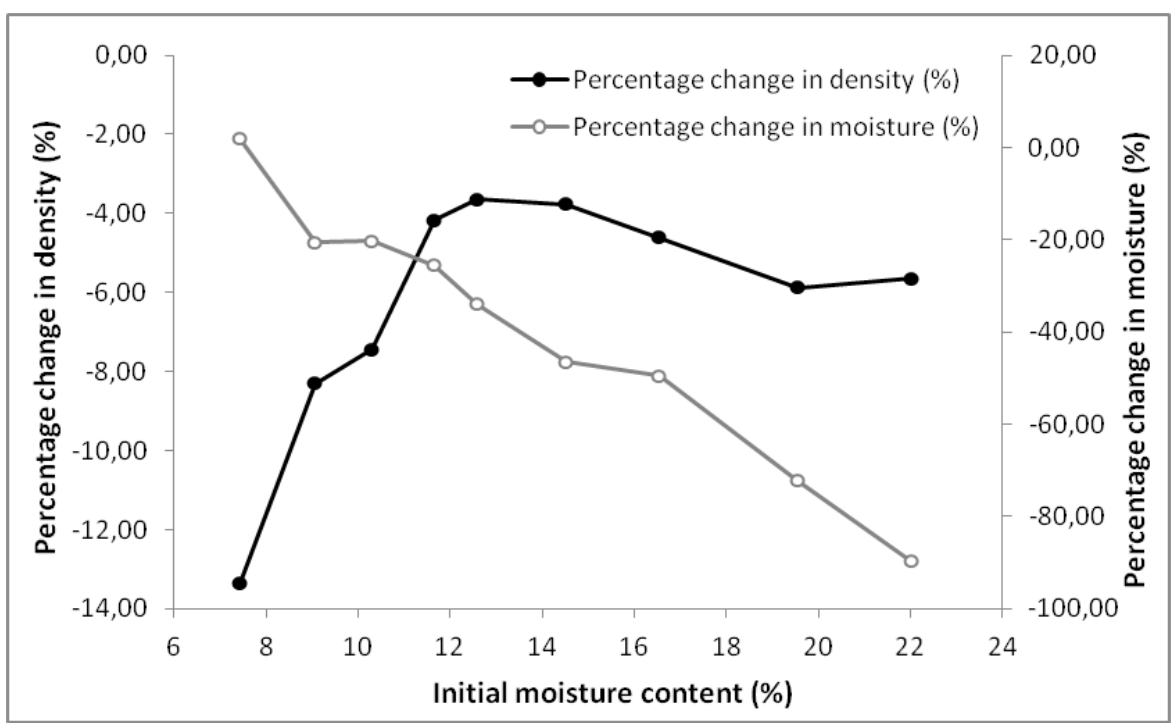

FiguRE 5. Percentage change in density and moisture of briquettes with initial moisture content of spruce sawdust after 5 days.

sawdust after five days. It also shows the percentage of the change in moisture content of the briquettes after five days with initial moisture content of spruce sawdust calculated on the basis of the initial moisture. This behaviour represents the global physical changes of the briquettes. Density change does not fully describe the physical changes. Although density is a function of mass and volume, not only the change in weight (water included) and dimensions needs to be controlled, but also the moisture changes separately. To evaluate the most stabile state of the briquettes, the changes of moisture content also needed to be included. The results shown in Fig. 6 as a cumulative absolute value of the physical changes reveal that the briquettes stored 5 days at indoor conditions (relative humidity $50-60 \%$, temperature around $20^{\circ} \mathrm{C}$ ) achieved the minimum of cumulative physical changes at up to $16.53 \%$ of initial moisture content. The percentage change in 5 days was calculated on the basis of the density and moisture of the briquettes measured 5 minutes after ejection from the die and then re-measured 5 days later.

\subsection{EFFECT OF THE CHANGE OF MOISTURE}

The initial moisture content of spruce sawdust was measured just before its densification. The moisture content of the briquettes was measured in two steps: 5 minutes and 5 days after the densification. The briquettes were stored at room temperature and stabile relative humidity of $50-60 \%$ in laboratory. Despite the pressing at low temperature (up to $30^{\circ} \mathrm{C}$ ), a slight decrease in moisture was detected already 5 minutes after ejection. A significant decrease in moisture was found 5 days after the densification. These results are shown in Fig. 6. The briquettes with different initial moistures had a tendency to achieve equilibrium 


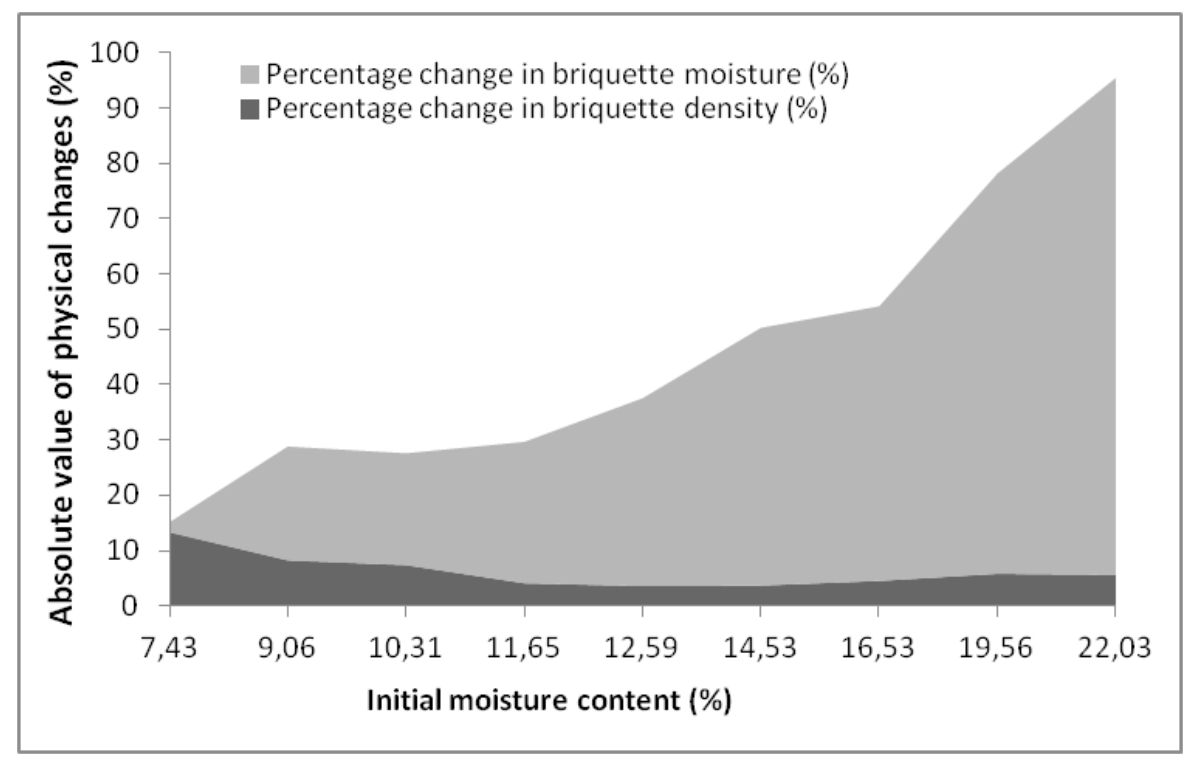

FigURE 6. Absolute value of both physical changes - percentage change in briquette moisture and percentage change in briquette density after 5 days.

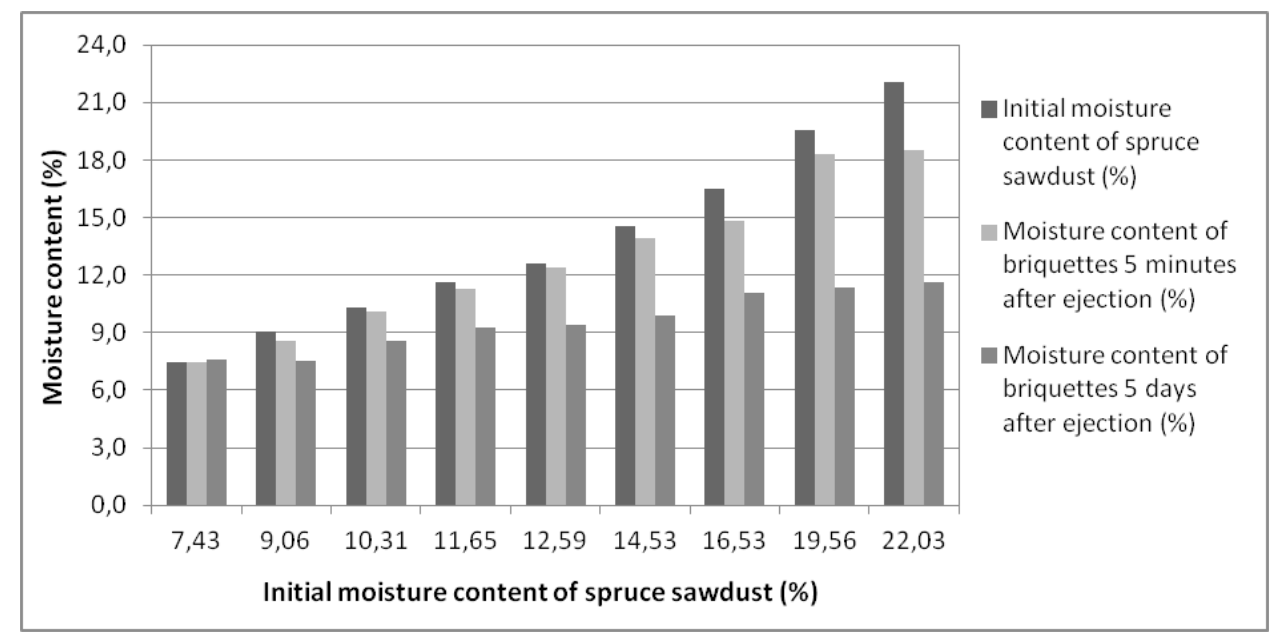

FIGURE 7. Comparison of moisture decline during the densification process and 5 days after ejection.

moisture content near $9 \%$ after 5 days already. There is a real assumption that after a couple more days the same equilibrium of different samples could be achieved, when stored under the same conditions.

\section{Conclunsions}

Spruce sawdust as a wood waste can be densified into high quality briquettes by high-pressure compaction. Briquettes were produced by industrial-scale process using a hydraulic briquetting press. For all briquettes studied, the same technical and technological conditions except the initial moisture content were retained. The appropriate moisture range for producing good quality briquettes ranges from 11 to $16 \%$, and the optimum is in the neighbourhood of $13 \%$. When the moisture content of the spruce sawdust is close to the optimum (13\%), already a pressure of $16.5 \mathrm{MPa}$ can produce briquettes with dry density higher than $0.8 \mathrm{~kg} \mathrm{dm}^{-3}$ (wet density higher than $0.9 \mathrm{~kg} \mathrm{dm}^{-3}$ ).
The best surface quality of the briquettes is possible to achieve in the range of moisture from $12.6 \%$ to $14.5 \%$. For the tested range of initial moisture content, the lower extensions and physical changes were proven up to $16.5 \%$ of moisture. When the effect of moisture change was studied, all briquettes with different initial moisture had the tendency to achieve equilibrium moisture content near $9 \%$ after 5 days of storage already.

When the spruce sawdust has an initial moisture content out of the 11-16\% range, the production of good quality briquettes by industrial-scale process using a hydraulic briquetting press is very difficult.

\section{ACKNOWLEDGEMENTS}

The research presented in this paper is an outcome of project APVV-0857-12: "Tools durability research of progressive compacting machine design and development of adaptive control for compaction process", funded by the Slovak Research and Development Agency. 


\section{REFERENCES}

[1] Kaliyan, N., Morey, R. V. Factors affecting strength and durability of densified biomass products. In: Biomass and Bioenergy, 33 (3), 2009, p. 337-359. DOI:10.1016/j.biombioe.2008.08.005

[2] Li Y, Liu H. High-pressure densification of wood residues to form an upgraded fuel. In: Biomass and Bioenergy, 2000, vol. 19, p. 177-186. DOI:10.1016/s0961-9534(00)00026-x

[3] EN 14774-3:2009, Solid biofuels - Determination of moisture content-oven dry method part 3: moisture in general analysis sample, European Committee for Standardization, Brussels, Belgium, 2009.

[4] Matúš, M., Križan, P. Modularity of pressing tools for screw press production solid biofuels. In: Acta Polytechnica. 2012, 52 (3), p. 71-76. DOI:10.14311/1558

[5] EN 16127:2012, Solid biofuels- Determination of length and diameter of pellets, European Committee for Standardization, Brussels, Belgium, 2012.

[6] Lisý, M. et al. Research into biomass and waste gasification in atmospheric fluidized bed. In: Proceedings of the 3rd WSEAS International Conference on Energy Planning, Energy Saving, Environmental Education, EPESE '09, Renewable Energy Sources, RES '09, Waste Management, WWAI '09. Canary Islands, Spain, 2009, pp. 363-368.

[7] Pietsch W. Agglomeration processes - phenomena, technologies, equipment. Weinheim: Wiley-VCH, 2002.

[8] Lisý, M., et al. Technical and Economic Optimization of Cogeneration Technology using Combustion and Gasification. In: Acta Polytechnica. 54, (1), 2014, p. 42-51. DOI:10.14311/ap.2014.54.0042

[9] Samuelsson, R. et al. Moisture content and storage time influence the binding mechanisms in biofuel wood pellets. In: Applied Energy. 2012, vol. 99, p. 109-115. DOI:10.1016/j.apenergy.2012.05.004

[10] Holm, J.K. et al. Toward an understanding of controlling parameters in softwood and hardwood pellets production. In: Energy Fuels, 2006, vol. 20, p.2686-2694. DOI:10.1021/ef0503360

[11] Pietsch, W. Size enlargement by agglomeration. John Willy \& Sons : New York, 1991.

[12] Kaliyan, N., Morey, R.V. Densification of Biomass: Mechanisms, Models, and Experiments on Briquetting and Pelleting of Biomass. VDm Verlag Dr. Muller 2008.

[13] Rumpf H. The strength of granules and agglomeration. In: Knepper WA, editor. Agglomeration. New York: John Wiley, 1962. p. 379-418.

[14] Tumuluru et. al. A Review on Biomass Densification Technologies for Energy Application. INL, Idaho, 2010. DOI:10.2172/1016196
[15] Grover, P. D., Mishra, S. K. Biomass Briquetting: Technology and Practices. Regional Wood Energy Development Programme in Asia, Field Document No. 46. Bangkok, Thailand: Food and Agricultural Organization of the United Nations, 1996.

[16] Mani, S., et al. Specific Energy Requirement for Compacting Corn Stover. In: Bioresource Technology, 2006, vol. 97, 1420-1426. DOI:10.1016/j.biortech.2005.06.019

[17] Tumuluru, J. S. et al. Quality of Wood Pellets Produced in British Columbia. In: Applied Engineering in Agriculture. 2010, 26 (6), p. 1013-1020. DOI:10.13031/2013.35902

[18] Thomas, M., et al. Quality of Pelleted Animal Feed 2. - Contribution of Processes and its Conditions. In: Animal Feed Science Technology. 1997, vol. 64, 173-192. DOI:10.1016/s0377-8401(96)01058-9

[19] Demirbas, A. et al. Briquetting Properties of Biomass Waste Materials. In: Energy Sources. 2004, vol. 26, 83-91. DOI:10.1080/00908310490251918

[20] Moshenin, N., Zaske J. Stress Relaxation and Energy Requirements in Compaction of Unconsolidated Materials. In: Journal of Agricultural Engineering Research. 1976, vol. 21, p. 193-205. DOI:10.1016/0021-8634(76)90065-2

[21] Sokhansanj, S. et al. Binderless Pelletization of Biomass. ASAE Paper No. 056061, ASAE, 2950 Niles Road, St. Joseph, MI 49085-9659 USA, 2005. DOI:10.13031/2013.19922

[22] Haussmann, F. Briquetting wood waste by the Fred Haussmann method. Institute of Briquetting and Agglomeration Proceedings. 1975, 14, p. 75-90.

[23] Rhén, C. et al. Effects of raw material moisture content, densification pressure and temperature on some properties of Norway spruce pellets. In: Fuel Processing Technology. 2005, vol. 87, p. 11- 16. DOI:10.1016/j.fuproc.2005.03.003 